\title{
GRATITUDE DAN PSYCHOLOGICAL WELLBEING PADA REMAJA
}

\author{
Adhyatman Prabowo \\ Fakultas Psikologi Universitas Muhammadiyah Malang \\ adhyatmanprabowo@umm.ac.id
}

Gratitude dan psychological well-being merupakan aspek emosi positif yang ada dalam individu. Individu yang memiliki rasa bersyukur karena mampu menyadari bahwa dirinya banyak menerima kebaikan, penghargaan baik dari Tuhan, orang lain dan lingkungan sekitarnya. Sedangkan individu yang memiliki psychological well-being ketika Ia mampu menerima dirinya, membentuk hubungan yang hangat, memiliki kemandirian, mengontrol lingkungan eksternal, memiliki arti dalam hidup serta merealisasikan potensi dirinya secara kontinyu. Tujuan penelitian ini adalah untuk mengetahui pengaruh Gratitude terhadap Psychological well being pada remaja. Penelitian menggunakan desain kuantitatif non eksperimen korelasional dua variabel. Teknik sampling yang digunakan dalam penelitian ini adalah menggunakan teknik cluster sampling. Teknik pengumpulan data dalam penelitian ini menggunakan skala Ryff's psychological well-being scale dan The Gratitude Questionnaires Six Item Form (GQ-6). Analisa data menggunakan metode analisa korelasional. Hasil penelitian menunjukkan bahwa tidak ada hubungan yang signifikan antara gratitude dan psychological well-being pada remaja $(\mathrm{r}=0,012$, $\mathrm{p}=0,865)$.

Kata kunci: Gratitude, psychological well-being, remaja.

Gratitude and psychological well being is a positive emotional aspect in every individual. People have gratitude on their self because they aware to get something good in every situation, a good appreciation from God and another people. Meanwhile, people who have psychological well being when they have self acceptance, positive relation to other people, have autonomy and mastering environment, have purpose in life and realizing their potential. The purpose of this study is to know the effect of gratitude towards psychological well being in adolescents. The research design used quantitative non-experimental study, correlating 2 variables. The sampling technique using cluster sampling. The data collected by using Ryff's Psychological Well-Being Scale formed by Caroll D. Ryff (1989) and The Gratitude Questionnaires Six Item Form $(G Q-6)$ be in the form of Likert Scale by McCullough (2002). The data analyzed by correlational analysis method. The result of this study show that there is no correlation between gratitude and psychological well-being in adolescent ( $r=0,012 ; p=0,865)$.

Keywords: Gratitude, psychological well-being, adolescents. 
Literatur yang mengkaji tentang penelitian mengenai psikologi positif menunjukkan bahwa gratitude pada remaja memberikan dampak positif bagi perkembangan emosi, sosial, dan well-being. Gratitude merupakan suatu bentuk emosi positif dalam mengekspresikan kebahagiaan dan rasa terimakasih terhadap segala kebaikan yang diterima (Seligman, 2002). Penelitian yang dilakukan Rotkirch (2014) menemukan bahwa gratitude berkolerasi dengan tingkat kedekatan personal terhadap teman sebaya maupun saudara bagi remaja. Ia menjelaskan bahwa remaja yang memiliki tingkat gratitude tinggi lebih dapat mengontrol emosi dirinya dalam menghadapi konflik dengan lingkungan sekitarnya sehingga dapat mempererat kedekatan personal dan keterikatan emosional dengan orang lain, terutama pada peer groupnya.

Menurut Kneezel dan Emmons (2006), gratitude meningkatkan personal well-being pada individu yang akan memenuhi kebutuhan psikologis dasar yaitu competence, autonomy dan relatedness. Sedangkan menurut Emmons \& McCullough (2004), gratitude akan membuat seseorang lebih bijaksana dalam menyikapi lingkungannya. Sedangkan jika seseorang kurang memiliki gratitude dalam dirinya, maka hal tersebut akan berpengaruh terhadap keharmonisan lingkungan yang telah ada. Disisi lain, hasil penelitian Froh, Kashdan, Ozimkowski, dan Miller (2009) yang menyatakan bahwa gratitude berkorelasi positif pada subjective well being, dukungan sosial, dan perilaku prososial remaja, seperti kepuasan hidup, optimisme, dan kontrol emosi. Hal ini diikuti pula oleh semakin meningkatnya perasaan emosi positif seperti sikap memaafkan, mendukung, dan memotivasi orang lain disekitarnya sehingga dapat mengembangkan hubungan interpersonal yang positif bagi remaja.

Gratitude didefinisikan sebagai emosi, nilai moral, sikap, personality trait dan coping style. Gratitude berasal dari bahasa Latin gratia yang berarti grace atau gratefulness (Lopez \& Snyder, 2003). Menurut Emmons (2007), segala kata yang berasal dari kata gratia selalu berhubungan dengan kebaikan, kemurahan hati, dan keindahan memberi maupun menerima. Gratitude memiliki kedudukan utama dalam berbagai pandangan filosofis maupun religius. Agama-agama seperti Islam, Kristen, Hindu dan Buddha telah mengakui pentingnya gratitude (Emmons dan Crumpler, 2000) sehingga gratitude disebut sebagai nilai terbesar dalam diri individu dan menjadi induk dari nilai-nilai kebaikan yang lain. Gratitude merupakan suatu bentuk emosi positif dalam mengekspresikan kebahagiaan dan rasa terimakasih terhadap segala kebaikan yang diterima (Seligman, 2002). Individu bersyukur karena menyadari bahwa dirinya banyak menerima kebaikan, penghargaan dan pemberian baik dari Tuhan, orang lain dan lingkungan sekitarnya sehingga terdorong untuk membalas, menghargai dan berterimakasih atas segala sesuatu yang diterimanya dalam bentuk perasaan, perkataan dan perbuatan.

Secara konseptual, gratitude terbagi dalam dua tingkat, yaitu state (keadaan) dan trait (sifat). Sebagai sebuah keadaan, gratitude berarti perasaan subjektif berupa kekaguman, berterimakasih dan menghargai segala sesuatu yang diterima. Sedangkan sebagai sifat, gratitude diartikan sebagai kecenderungan seseorang untuk merasakan gratitude dalam hidupnya, meskipun kecenderungan untuk merasakan gratitude itu tidak selalu muncul namun seseorang yang memiliki kecenderungan ini akan lebih sering berterimakasih dalam situasi-situasi tertentu. Mc Cullough, Emmons, dan Tsang (2002) membedakan trait gratitude dalam empat aspek, yaitu: pertama, Intensity, artinya sangat bersyukur Jurnal Ilmiah Psikologi Terapan 
ketika terjadi hal-hal positif. Kedua, Frequency artinya individu sering mengungkapkan rasa syukur setiap hari. Ketiga, Span artinya individu merasa bersyukur dalam berbagai keadaan hidup (seperti bersyukur atas pekerjaan, kesehatan dan keluarga yang dimiliki). Keempat, Density artinya individu sering merasakan perasaan berterimakasih terhadap lebih banyak orang.

McCullough, et al. (2002) menyatakan bahwa ada beberapa faktor yang mempengaruhi gratitude yaitu: Pertama, Emotionality yaitu suatu kecenderungan dimana seseorang merasa emosional dan menilai kepuasan hidupnya. Kedua, Prosociality yaitu kecenderungan seseorang untuk diterima di lingkungan sosial. Ketiga, Religiousness yaitu sesuatu yang berkaitan dengan nilai-nilai transendental, keagamaan dan keimanan seseorang.

Psychological well-being adalah sebagai kemampuan individu untuk menerima diri apa adanya, membentuk hubungan yang hangat dengan orang lain, memiliki kemandirian dalam menghadapi lingkungan sosial, mengontrol lingkungan eksternal, menetapkan tujuan hidupnya, dan merealisasikan potensi dirinya secara kontinu. Kemampuan tersebut dapat diupayakan dengan cara memfokuskan pada realisasi diri, pernyataan diri dan pengaktualisasian potensi dirinya sehingga dapat berfungsi positif secara penuh dan meraih kebahagiaan (Ryff, 1989).

Konsep Psychological well-being yang digambarkan oleh Ryff (1989) terdiri dari enam dimensi, yaitu : penerimaan diri, hubungan positif dengan orang lain, otonomi, penguasaan lingkungan, tujuan hidup dan pertumbuhan pribadi. Adapun faktor-faktor yang mempengaruhi Psychological well-being yaitu; pertama adalah usia, hasil penelitian menunjukkan bahwa otonomi, penguasaan lingkungan, tujuan hidup dan perkembangan pribadi meningkat seiring dengan meningkatnya usia. Selain itu Pengukuran penerimaan diri dan hubungan positif tidak ditunjukkan oleh perbedaan usia (Keyes \& Waterman, 2003). Kedua adalah jenis kelamin, perbedaan jenis kelamin memiliki pengaruh pada Psychological well-being seseorang, dimana wanita cenderung lebih memiliki Psychological well-being dibandingkan laki-laki. Hal ini terkait dengan pola fikir yang berpengaruh terhadap strategi koping dan aktivitas sosial yang dilakukan, dimana wanita lebih cenderung memiliki kemampuan interpersonal yang lebih baik daripada laki-laki (Snyder, 2002). Ketiga adalah dukungan sosial, penelitian yang telah dilakukan menunjukkan hasil bahwa terdapat hubungan yang signifikan antara interaksi sosial dengan Psychological well-being (Nezar, 2009).

Terdapat sedikit kesamaan konsep dalam gratitude dan psychological well-being, yakni keduanya sama-sama merupakan keadaan positif yang dimiliki oleh individu. Aspek pertama dalam psychological well-being adalah penerimaan diri (self-acceptance). Ryff (1989) menjelaskan bahwa penerimaan diri ditunjukkan oleh individu yang dapat mengevaluasi positif terhadap dirinya sekarang dan dirinya di masa lalu. Ketika seseorang mampu bersyukur dan mengambil sisi positif dari apa yang didapatkannya, maka orang tersebut sudah tentu akan dapat lebih mudah mencapi aspek well-being yaitu penerimaan diri.

Individu yang memiliki rasa syukur dalam dirinya akan menyadari dan senantiasa mengambil hal-hal positif sehingga Ia mampu mempersepsikan dirinya bahwa Ia Jurnal Ilmiah Psikologi Terapan 
menerima banyak kebaikan dan pemberian baik dari Tuhan maupun orang di lingkungan sekitarnya sehingga mampu meningkatkan motivasinya untuk berlaku baik dan membalas kebaikan tersebut pada orang lain dalam bentuk perbuatan, perkataan, maupun perasaan dan pada akhirnya akan dapat menciptakan hubungan yang positif dengan orang lain, mandiri, dan mampu berfungsi sepenuhnya dalam lingkungan sosial. Hal ini senada dengan yang diungkapkan oleh Emmons dan Mishra (2010) yang menyatakan bahwa gratitude adalah dasar kesejahteraan (well-being) dan kesehatan mental sepanjang hidup manusia. Dari masa kanak-kanak hingga usia tua, akumulasi dari keadaan positif secara psikologis, fisik, maupun hubungan relasi dikaitkan dengan gratitude.

Remaja berkembang sangat berkaitan erat dengan lingkungan (Papalia, Olds, Feldman, 2009). Lingkungan sosial yang berpengaruh bagi remaja adalah sekolah yang merupakan elemen penting dalam proses perkembangan individu karena berfungsi pemilihan karir di masa mendatang dan merupakan sarana pembelajaran mengenai pengetahuan tentang peran sosial dan batasan norma. Selaras dengan konsep Organization for Economic CoOperation and Development (OECD) yang dijadikan rujukan oleh Kementerian Pendidikan Nasional Indonesia dalam mengevaluasi penyelenggaraan fungsi dan peran sekolah di Indonesia telah merekomendasikan adanya parameter kualitatif dalam evaluasi seperti di Inggris dan Wales, yaitu berupa aspek spiritual, moral, sosial budaya, dan kontribusi sekolah dalam pengembangan well-being siswa (Faubert, dalam Ahmad 2011).

Namun faktanya, peran sekolah tampak belum optimal bila ditinjau dari tingkat prosentase kenakalan remaja di Indonesia masalah kenakalan remaja di Indonesia semakin memprihatinkan dan menjelma menjadi masalah sosial yang kritis karena telah mengarah pada berbagai bentuk tindakan kriminalitas. Berbagai hasil survei menjelaskan mengenai bentuk kenakalan remaja yang semakin meningkat, misalnya survei yang dilakukan BNN (Badan Narkotika Nasional) yang menemukan bahwa $50-60 \%$ sebanyak 3,8 sampai 4,2 juta pengguna narkoba di Indonesia dilakukan oleh remaja (detikhealth, Rabu, 6 Juni 2012).

Disisi lain, sexual behaviour survey 2011 menemukan bahwa $64 \%$ remaja di kota-kota besar di Indonesia telah melakukan hubungan seksual akibat perkembangan pornografi dan pornoaksi yang semakin mudah diakses. Akibatnya, perilaku aborsi yang dilakukan juga semakin meningkat seperti halnya ditunjukkan hasil survei BKKBN LDFE UI (2000) bahwa di Indonesia terjadi 2,4 juta kasus aborsi / tahun yang dilakukan oleh remaja. Selain itu, hasil survei yang dilakukan Komisi Perlindungan Anak Indonesia (KPAI) pada tahun 2012 menunjukkan adanya sedikitnya 139 kasus tawuran yang dilakukan remaja SMP dan SMA (Liputan 6.com 27 Desember 2012).

Dari beberapa paparan data di atas tentang fenomena remaja di sekolah, dapat diketahui bahwa remaja di Indonesia belum mencapai tingkat psychological well-being yang optimal. Apabila kita merujuk dalam pengertian psychological well-being yang dikemukakan oleh Ryff (1989).

Hal ini disebabkan karena mereka belum mampu meregulasi dirinya dan menjadi adaptif sesuai dengan norma yang berlaku di lingkungan sekitar. Disisi lain, kondisi emosi remaja yang belum stabil juga mempengaruhi terjadinya kenakalan remaja tersebut. Seperti yang diungkapkan oleh McCullough, et al. (2002) yang menyatakan bahwa faktor Jurnal Ilmiah Psikologi Terapan 
yang mempengaruhi gratitude yaitu suatu kecenderungan dimana seseorang merasa emosional dan menilai kepuasan hidupnya. Selain itu, psychological well-being dapat membantu remaja untuk menumbuhkan emosi positif, merasakan kepuasan hidup dan kebahagiaan, mengurangi depresi, dan perilaku negatif remaja Akhtar (2009).

Dari beberapa penjelasan diatas dapat disimpulkan peran gratitude dan pentingnya Psychological Well-Being bagi remaja. Oleh karena itu, penelitian ini bertujuan untuk mengetahui pengaruh gratitude terhadap Psychological well-being pada remaja.

\section{Hipotesa Penelitian}

Hipotesa penelitian ini adalah ada hubungan antara gratitude dan psychological wellbeing remaja. Semakin tinggi gratitude maka semakin tinggi tingkat psychological wellbeing yang dimiliki oleh remaja.

\section{METODE}

\section{Rancangan Penelitian}

Rancangan yang digunakan dalam penelitian ini adalah metode kuantitatif merupakan suatu pendekatan penelitian dimana banyak menggunakan angka mulai dari pengumpulan data, penafsiran data hingga penampilan hasilnya. Adapun jenis metode kuantitatif yang digunakan dalam penelitian ini adalah menggunakan kuantitatif korelasional dua variabel, yaitu menguji adanya pengaruh anatara variabel independent dan dependen (Sugiyono, 2012).

\section{Subjek Penelitian}

Subjek penelitian ini adalah remaja Sekolah Menengah Kejuruan Muhmmadiyah di Kota Malang. Remaja yang dimaksud berusia 15- 20 tahun yang tinggal di Kota Malang dan berstatus pelajar. Teknik pengambilan sampel yang digunakan adalah metode cluster sampling. Cluster sampling merupakan pengambilan sample yang didasarkan pada area atau cluster. Cluster yang dimaksud dalam penelitian ini adalah kelas-kelas yang ada di dalam sekolah. Subjek penelitian berjumlah 224 orang.

\section{Variabel dan Intrumen penelitian}

Variabel terikat dalam penelitian ini adalah Psychological well-being yang dimaksud adalah kondisi individu yang mampu menerima dirinya apa adanya, mampu membentuk hubungan yang hangat dengan orang lain, memiliki kemandirian terhadap tekanan sosial, mampu mengontrol lingkungan eksternal, memiliki arti dalam hidup serta mampu merealisasikan potensi dirinya secara kontinyu. Metode pengumpulan data dalam penelitian ini menggunakan skala Psychological well-being yang disusun oleh Ryff (1989) yang telah diadaptasi dan dikembangkan oleh peneliti yang terdiri dari 42 item. Skala ini memiliki 6 dimensi yaitu Autonomy (Otonomi), Enviromental mastery (Penguasaan Lingkungan), Personal Growth (Pengembangan Pribadi), Positive Relations with others (hubungan positif dengan orang lain), Purpose in Life (Tujuan Hidup) dan Self-Acceptance (Penerimaan Diri). Jenis skala menggunakan model likert dengan lima 
pilihan jawaban mulai sangat tidak setuju (1) sampai sangat setuju (6). Skoring dapat dilakukan dengan menjumlah total nilai tiap item. Semakin tinggi nilai maka semakin tinggi tingkat kesejahteraan psikologis. Kualitas instrumen yang akan digunakan untuk mengumpulkan data dilakukan uji validitas dan reliabilitas adapun hasilnya adalah skala Psychological well-being berkisar antara 0,316 - 0,613. Sedangkan uji reliabilitas sebesar 0,756, maka dapat disimpulkan bahwa instrument yang dipakai dalam penelitian ini reliabel (Nazir, 2003).

Variabel bebas dalam penelitian ini adalah adalah gratitude yaitu suatu kondisi dimana individu merasa bersyukur atas segala sesuatu yang diterima atau dialami dalam hidupnya. Metode pengumpulan data gratitude dengan menggunakan The Gratitude Questionnaires Six Item Form (GQ-6) berupa skala likert yang disusun oleh McCullough, et al. (2002) berjumlah 6 aitem. Uji validitas menunjukkan hasil 0,3490,625 dan reliabilitas sebesar 0.756 .

\section{Prosedur dan Analisa Data}

Penelitian ini dimulai dengan mempersiapkan instrumen. Instrumen dari dua variabel penelitian ini seluruhnya diadaptasi dari instrumen penelitian berbahasa Inggris yang telah disusun oleh peneliti sebelumnya. Proses adaptasi dimulai dengan menerjemahkan instrumen penelitian melalui lembaga Language Center Universitas Muhammadiyah Malang, kemudian peneliti melakukan penyesuaian dalam susunan item. Selanjutnya peneliti melakukan try out instrumen. Selanjutnya peneliti melaksanakan kegiatan penelitian. Analisa data dalam penelitian ini menggunakan analisis korelasional untuk menguji hubungan antar-variabel. Proses analisa data menggunakan teknik korelasi product moment dari pearson. Proses ini menggunakan software perhitungan statistik yaitu SPSS for windows versi 21. Sebelum melakukan analisis korelasi, terlebih dahulu peneliti melakukan uji prasyarat korelasi yaitu uji normalitas data. 


\section{HASIL PENELITIAN}

Penelitian ini dilakukan kepada 224 Remaja yang memiliki karakteristik sebagai berikut:

Tabel 1. Deskripsi Subjek Penelitian

\begin{tabular}{|c|c|c|}
\hline Kategori & Frekuensi & Prosentase \\
\hline \multicolumn{3}{|l|}{ Jenis Kelamin } \\
\hline Laki-laki & 145 & $64,7 \%$ \\
\hline Perempuan & 79 & $35,3 \%$ \\
\hline \multicolumn{3}{|l|}{ Usia } \\
\hline$\leq 14$ & 0 & $0 \%$ \\
\hline $15-16$ & 116 & $52 \%$ \\
\hline $17-18$ & 103 & $46 \%$ \\
\hline$\geq 19$ & 5 & $2 \%$ \\
\hline \multicolumn{3}{|l|}{ Sekolah } \\
\hline SMK Muhammadiyah 2 Malang & 59 & $26,3 \%$ \\
\hline SMK Muhammadiyah 1 Malang & 22 & $9,8 \%$ \\
\hline SMK Muhammadiyah 1 Kepanjen & 59 & $26,3 \%$ \\
\hline SMK Muhammadiyah 3 & 18 & $8,0 \%$ \\
\hline SMK Muhammadiyah 7 Gondanglegi & 66 & $29,5 \%$ \\
\hline
\end{tabular}

Dari Tabel 1 dapat diketahui bahwa dari 224 responden penelitian terdapat jumlah responden yang berjenis kelamin laki-laki sebanyak 145 orang $(64,7 \%)$ dan responden berjenis kelamin perempuan sebanyak 79 (35,3\%). Kemudian, jika dilihat berdasarkan usia responden, dari 224 subjek penelitian, tidak ada responden yang berada pada rentangan usia $\leq 14(0 \%), 116$ responden $(52 \%)$ berada pada rentangan 15 - 16 tahun, 103 responden $(46 \%)$ berada pada rentangan usia 17 - 18 tahun, dan 5 responden $(2 \%)$ berada pada rentangan usia $\geq 19$.

Kategori responden penelitian juga diambil berdasarkan pada sekolah. Dari 224 responden, 59 siswa (26,3 \%) berasal dari SMK Muhammadiyah 2 Malang, 22 siswa $(9,8$ $\%$ ) berasal dari SMK Muhammadiyah 1 Malang, 59 siswa $(26,3 \%)$ berasal dari SMK Muhammadiyah 1 Kepanjen, 18 siswa $(8,0 \%)$ berasal dari SMK Muhammadiyah 3, dan 66 siswa $(29,5 \%)$ berasal dari SMK Muhammadiyah 7 Gondanglegi.

Tabel 2. Perhitungan Tabulasi Skala Psychological Well-Being dan Gratitude

\begin{tabular}{llcc}
\hline \multicolumn{1}{c}{ Variabel } & Kategori & Frekuensi & Prosentase \\
\hline Psychological Well-Being & Tinggi & 103 & $46 \%$ \\
& Rendah & 121 & $54 \%$ \\
Gratitude & Tinggi & 105 & $46,9 \%$ \\
& Rendah & 119 & $53,1 \%$ \\
\hline
\end{tabular}

Berdasarkan hasil analisa tabulasi deskripsi data dengan variabel dapat diketahui bahwa dari 224 subjek penelitian, terdapat 103 responden (46 \%) yang tergolong memiliki tingkat psychological well-being yang tinggi. Sedangkan sisanya yaitu sejumlah 121 responden $(54 \%)$ memiliki psychological well-being yang tergolong masih rendah. 
Pada variabel gratitude, dapat diketahui yaitu 105 responden $(46,9 \%)$ memiliki tingkat gratitude yang tinggi, dan 119 responden $(53,1 \%)$ memiliki tingkat gratitude yang rendah. Berdasarkan hasil uji korelasi diketahui bahwa signifikansi 0,859 (>0,05) maka Ho diterima, Ha ditolak. Sehingga dapat diambil kesimpulan bahwa tidak terdapat hubungan positif yang signifikan antara gratitude dan psychological well-being pada remaja.

\section{DISKUSI}

Dari penelitian yang telah dilakukan, didapatkan hasil bahwa tidak ada hubungan positif yang signifikan antara gratitude dengan psychological well-being pada remaja $(\mathrm{p}=$ 0,859). Hal ini menunjukkan bahwa ketika gratitude pada remaja ini tinggi, belum tentu diikuti dengan psychological well-being yang tinggi pula. Sebaliknya, semakin rendah gratitude yang dimiliki oleh remaja, belum tentu diikuti pula dengan rendahnya tingkat psychological well-being individu pada usia remaja.

Hasil penelitian ini tampaknya berbeda dengan hasil-hasil penelitian yang telah dilakukan peneliti lain sebelumnya dengan mengambil variabel yang sama namun subjek yang dipilih berbeda. Seperti penelitian yang dilakukan oleh Putri (2012) terhadap mahasiswa di Universitas Indonesia. Hasil dari penelitian Putri menyatakan bahwa terdapat hubungan positif yang signifikan antara gratitude dan psychological well-being pada mahasiswa. Selain itu, terkait dengan keterlibatan responden dalam perkumpulan keagamaan menunjukkan bahwa tidak terdapat perbedaan yang signifikan baik pada gratitude maupun psychological well-being antara responden yang tergabung dan tidak tergabung dalam perkumpulan keagamaan.

Namun demikian, terdapat penelitian lain yang sejalan dengan hasil yang didapatkan oleh peneliti dalam studi ini. Seperti penelitian yang dilakukan oleh Sood dan Gupta (2012) terhadap orang dewasa di dua distrik yaitu Jammu dan Kashmir di India. Hasil penelitiannya menunjukkan bahwa tidak ada hubungan antara gratitude dan well-being khususnya pada usia dewasa yang menjadi subjek pada penelitian. Hal ini mematahkan anggapan bahwa gratitude tidak selalu mempengaruhi well-being pada usia dewasa. Artinya, dapat dikatakan ada faktor-faktor lain yang sebenarnya lebih mempengaruhi pada peningkatan well-being seseorang daripada gratitude meski secara teoritis menunjukkan bahwa gratitude akan meningkatkan psychological well-being pada seseorang.

Emotionality merupakan salah satu faktor yang mempengaruhi munculnya gratitude pada seorang individu (McCullough, et al., 2002). Secara konseptual, gratitude memang sebuah keadaan individu dimana individu tersebut merasa kagum, berterimakasih, dan menghargai segala sesuatu yang diterima. Dari pernyataan ini, maka dapat dikatakan bahwa gratitude akan muncul ketika seorang individu berada pada keadaan yang positif terutama secara emosi sehingga dapat memunculkan afek positif dalam diri individu tersebut.

Seperti yang kita ketahui secara teoritis, masa remaja merupakan masa transisi dari usia kanak-kanak menuju dewasa. Pada rentangan perkembangan ini, remaja akan banyak mengalami konflik dan perubahan di diri mereka. Satu hal yang sering menjadi fokus 
tentang perkembangan remaja adalah belum matangnya individu tersebut terutama dalam hal emosi. Hal ini tentu akan berdampak pada bagaimana cara individu maupun seorang remaja dalam menghadapi suatu situasi atau konflik yang sedang dihadapinya. seperti yang diungkapkan oleh Sood dan Gupta (2012) bahwa kemungkinan mereka yang berusia 16 hingga 19 tahun lebih sering dihadapkan pada situasi yang penuh konflik atau stress dibandingkan pada usia sebelumnya. Apabila ditelaah dari penjelasan diskusi di atas, maka dapat ditarik benang merah bahwa remaja memang belum stabil dalam hal emosi, hal ini pada akhirnya membuat gratitude yang dimiliki remaja tersebut belum berkembang karena dilihat dari salah satu faktor yang mempengaruhi gratitude adalah keadaan secara emosional yang positif.

Seseorang dapat dikatakan memiliki psychological well-being adalah ketika seseorang tersebut mampu menjalin hubungan positif dengan orang lain. Papalia, et al. (2009) menjelaskan bahwa satu hal yang paling penting dalam masa remaja adalah penerimaan sosial. Pada usia ini, para remaja akan mulai terlepas dari orangtua dan lebih banyak berinteraksi dengan teman sebayanya. Mereka akan banyak menjalin relasi dengan orang lain dan berusaha untuk dapat diterima secara sosial. Oleh karena itu, gratitude tampaknya bukan menjadi satu-satunya yang mempengaruhi psychological well-being individu meskipun secara tidak langsung dapat dimasukkan dalam konsep penerimaan diri dalam dimensi psychological well-being.

\section{SIMPULAN DAN IMPLIKASI}

Berdasarkan hasil penelitian ini diperoleh hasil bahwa hipotesis penelitian ditolak yang berarti bahwa tidak ada hubungan yang signifikan antara gratitude dan psychological well-being pada remaja $(\mathrm{r}=0,012, \mathrm{p}=0,865)$. Nilai signifikansi $(0,865>0,05)$ lebih besar dari taraf signifikansi yang digunakan $5 \%$. Untuk peneliti selanjutnya yang akan melanjutkan penelitian dengan variable gratitude lebih baik mempertimbangkan tahapan perkembangan psikologi.

Implikasi dari penelitian ini adalah remaja kurang berkontribusi terhadap peran gratitude terhadap psychological well-being. Hal ini terbukti gambaran tingkat gratitude remaja masih banyak yang rendah. Selain itu, menggali lebih dalam dan mengembangkan faktor faktor yang mempengaruhi psychological well-being pada remaja. Berikutnya untuk peneliti selanjutnya

\section{REFERENSI}

Ahmad, J, N. (2010). Penggunaan school well being pada Sekolah Menengah Kejuruan (SMK) bertaraf internasional sebagai barometer evaluasi sekolah. Jakarta, Jurnal UI Untuk Bangsa Seri Sosial dan Humaniora 1 Desember 2010.

Akhtar, M. (2009). Applying positive psychology to alcohol-misusing adolescents: A pilot intervension. Disertation. United Kingdom : Msc applied positive psychology on University of East London. 
BKKBN. (2007). Laporan: Pencapaian presentase KB Indonesia tahun 2007. Jakarta : BKKBN Jakarta.

Ryff, C. D. (1989). Happiness is everything, or is it? explorations on the meaning of psychological well-being Journal American Psychological Association 57, (6), 1069-1081.

Emmons, R. A., \& Crumpler, C. A. (2000). Gratitude as a human strength: Appraising the evidence. Journal of Social and Clinical Psychology, 19, 56-69.

Emmons, R.A., \& Mc Cullough, M. E. (2004). The psychology of gratitude. New York: Oxford University Press.

Emmons, R. A. (2007). Thanks! How the new science of gratitude can make you happier. New York: Houghton Mifflin Company.

Froh, J.J., Kashdan, T.B., Ozimkowski, K.M., \& Miller, N. (2009). Who benefits the most from gratitude intervention in children and adolescence? Examining positive affect as a moderator. The Journal of Positive Psychology, 4, 408-422.

Keyes, C. L. M., \& Waterman, M. B. (2003). Dimensions of well-being and mental health in adulthood. Diakses dari http://psycnet.apa.org/psycinfo/2003-02621033 pada 3 Agustus 2016

Kneezel, T., \& Emmons, R. A. (2006). Personality and spiritual development. The handbook of spiritual development in childhood and adolescence (266-278). Thousand Oaks, CA: Sage Publications.

McCullough, M. E., Emmons, R.A., \& Tsang, J. (2002). The grateful disposition: A conceptual and empirical topography. Journal of Personality and Social Psychology, 82, 112-127.

Lopez, S. J., \& Snyder, C.R. (2003). Positive psychological assessment: A handbook of models and measures. Washington. DC: American Psychological Association.

Nazir, M. (2003). Metode penelitian. Jakarta: Penerbit Ghalia Indonesia

Nezar, R. (2009) Psychological well-being pada lansia di panti jompo. Skripsi Fakultas psikologi Universitas Muhammadiyah Malang.

Papalia, Olds, \& Feldman. (2009). Human development. New York, USA : Mc GrawHill.

Putri, F. O. (2012). Hubungan antara gratitude dan psychological well-being pada mahasiswa. Skripsi Fakultas Psikologi Universitas Indonesia.

Rotkirch, A. (2014) Gratitude for help among adult friends and siblings. The Journal of Evolutionary Psychology, 12, (4): 673-686. 
Seligman, M. E. P. (2002). Authentic happiness: Using the new positive psychology to realize your potential for lasting fulfillment. New York: Free Press.

Sood, S., \& Gupta, R. (2012). A study of gratitude and well-being among adolescents. Journal of Humanities and Social Science, 3, (5).

Sugiyono. (2012). Metode penelitian kuantitatif kualitatif dan $R \& B$. Bandung: Alfabeta. 